\title{
CONSERVATION BIOLOGY OF FRESHWATER TURTLES AND TORTOISES
}

A Compilation Project of the

IUCN/SSC Tortoise and Freshwater Turtle Specialist Group

\section{EDITED BY}

Anders G.J. Rhodin, John B. Iverson, Peter Paul van Dijk, Craig B. Stanford, Eric V. Goode, Kurt A. Buhlmann, and Russell A. Mittermeier

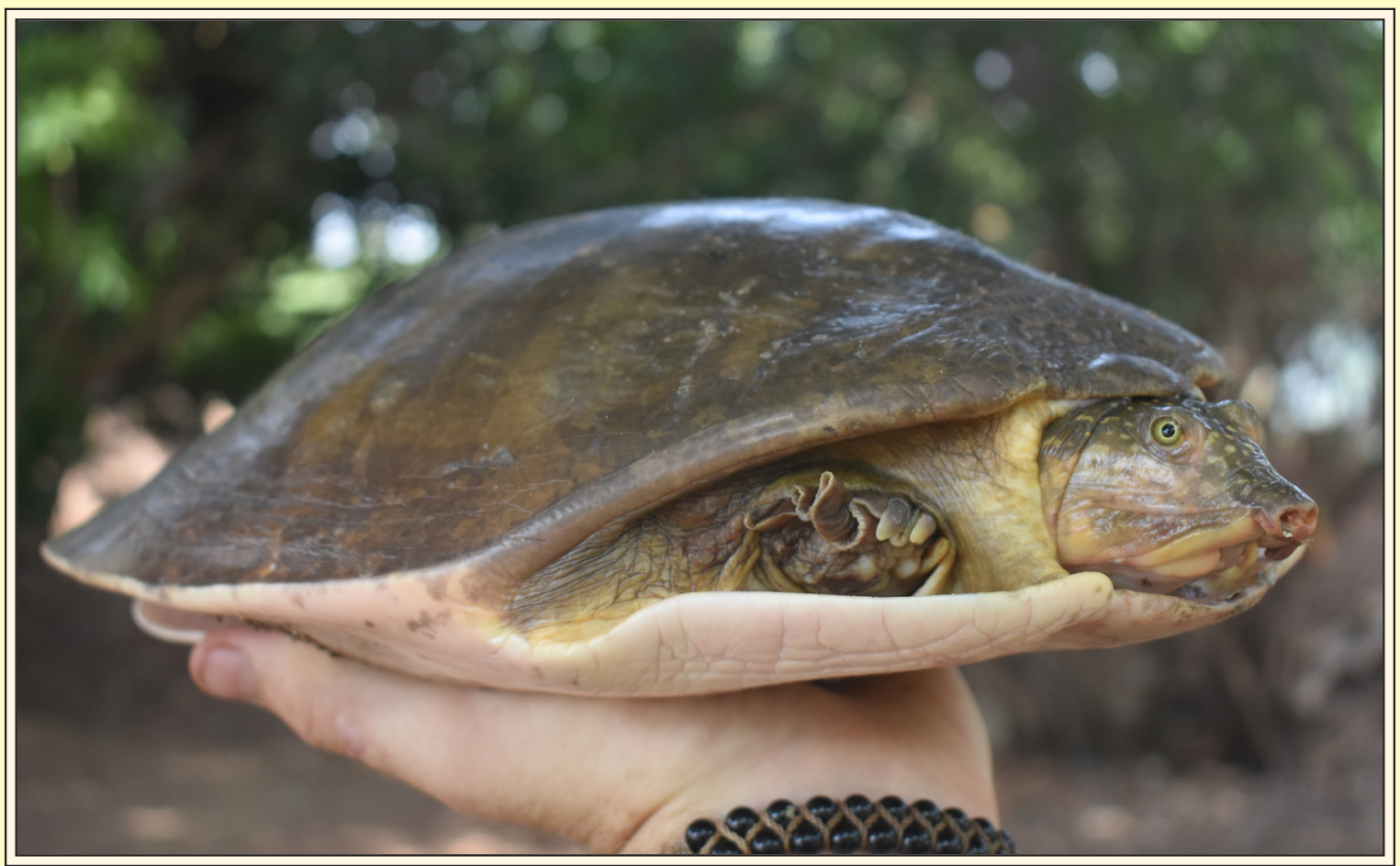

Cyclanorbis senegalensis (Duméril and Bibron 1835) Sahelian Flapshell Turtle, Senegal Flapshell Turtle

Pearson McGovern, Tomas Diagne, Lamine Diagne, Luca Luiselli, and Peter A. Meylan

Chelonian Research Monographs

Number 5 (Installment 15) 2021: Account 114

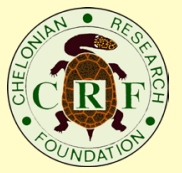

\author{
Published by \\ Chelonian Research Foundation and Turtle Conservancy \\ in association with \\ IUCN/SSC Tortoise and Freshwater Turtle Specialist Group, Re:wild,
}

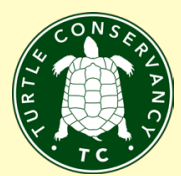

Turtle Conservation Fund, and International Union for Conservation of Nature / Species Survival Commission 


\title{
Cyclanorbis senegalensis (Duméril and Bibron 1835) - Sahelian Flapshell Turtle, Senegal Flapshell Turtle
}

\author{
Pearson McGovern ${ }^{1}$, Tomas Diagne ${ }^{1}$, Lamine Diagne ${ }^{2}$, \\ Luca Luiselli ${ }^{3,4,5}$, and Peter A. Meylan ${ }^{6}$ \\ ${ }^{1}$ African Chelonian Institute, BP 80 Joal, Thies 23015, Senegal \\ [pmcgovern@africanchelonian.org,tdiagne@africanchelonian.org,africanci@gmail.com]; \\ ${ }^{2}$ Village des Tortues, Noflaye,Dakar,Senegal [laminedestortues@yahoo.fr]; \\ ${ }^{3}$ Institute for Development, Ecology, Conservation \& Cooperation, via G. Tomasi di Lampedusa 33, \\ I-00144 Rome, Italy [l.luiselli@ideccngo.org; lucamaria.luiselli@uniroma3.it]; \\ ${ }^{4}$ Department of Zoology, University of Lomé, Togo; \\ ${ }^{5}$ Department of Environmental and Applied Biology, Rivers State University of Science and Technology, \\ P.M.B. 5080, Port Harcourt, Nigeria; \\ ${ }^{6}$ Natural Science, Eckerd College, 420054 th Ave. South, \\ St.Petersburg, Florida 33711 USA [meylanpa@eckerd.edu]
}

Summary. - The Sahelian Flapshell Turtle, Cyclanorbis senegalensis (family Trionychidae) is the most widely distributed of the African members of the trionychid subfamily Cyclanorbinae, occurring across the sub-Saharan Sahel region from Senegal to Ethiopia. It is a moderate sized, sexually size-dimorphic freshwater turtle with females (curved carapace length [CCL] up to ca. $38 \mathrm{~cm}$ ) much larger than males (CCL up to $\mathrm{ca} .19 \mathrm{~cm}$ ). There are only minimal data available concerning the preferred habitats, natural history, and ecology of African cyclanorbines, including this species, but it apparently prefers medium sized rivers (5-25 m river-bed width) or waterbodies off main river channels with at least sparse emergent vegetation, grassy, semi- or highly-vegetated banks, and predominantly muddy bottoms. Nesting appears to occur primarily in April and the clutch size may be small (only a single clutch of 6 round eggs measuring $36 \mathrm{~mm}$ in diameter has been reported); hatchlings measure ca.41-54 mm straight carapace length.Cyclanorbis senegalensis and other African softshell turtles are frequently used by local people for food, and when coupled with habitat degradation, the potential for local extirpation and increased global vulnerability of this species is of concern.

Distribution. - Apparently disjunct and fragmented distribution across the sub-Saharan Sahel from Senegal in the west to western Ethiopia in the east. Benin, Burkina Faso, Cameroon, Central African Republic, Chad, Ethiopia, Gambia, Ghana, Guinea, Guinea-Bissau, Ivory Coast (Côte d'Ivoire), Liberia, Mali, Mauritania, Niger, Nigeria, Senegal, Sierra Leone, South Sudan, Sudan, Togo.

Synonymy.-Cryptopus senegalensis Duméril and Bibron 1835, Emyda senegalensis, Cyclanosteus senegalensis, Cyclanorbis petersii Gray 1854, Cyclanosteus petersii,Cycloderma petersii, Cycloderma senegalense Duméril 1861 (nomen novum), Tetrathyra baikii Gray 1865a,Cyclanosteus senegalensis callosa Gray 1865b, Cyclanosteus senegalensis equilifera Gray 1865b, Cyclanosteus senegalensis normalis Gray 1865b, Tetrathyra vaillantii Rochebrune 1884.

SubSPECIES. - None currently recognized.

STATUS. - IUCN 2021 Red List Status: Vulnerable (VU A2bcd+4bed, assessed 2016); CITES: Appendix II.

Taxonomy. - Cyclanorbis senegalensis was described by Duméril and Bibron (1835) on the basis of a young specimen preserved at the Museum National d'Histoire Naturelle (MNHN 4151; see Bour et al. 1995) in Paris, with a type locality of Senegal. Ontogenetically limited type material and the rarity of Cyclanorbis specimens in public collections has led to some confusion with its sympatric congener, Cyclanorbis elegans Gray 1869 , and other African members of the trionychid subfamily Cyclanorbinae (Gray 1860). Tetrathyra baikii
Gray 1865a, based on two subadult specimens from western Africa (probably from the Niger River), is synonymous with $C$. senegalensis, as is Cyclanorbis petersii Gray 1854 from Gambia. Gray (1865b) also described three varieties of $C$. senegalensis, none of which are currently recognized as distinct: C.s.equilifera, C.s.normalis, and C. s. callosa. In addition, Rochebrune (1884) described Tetrathyra vaillantii, also considered a synonym of $C$. senegalensis. Early publications describing Cyclanorbis species must be carefully scrutinized to determine which 


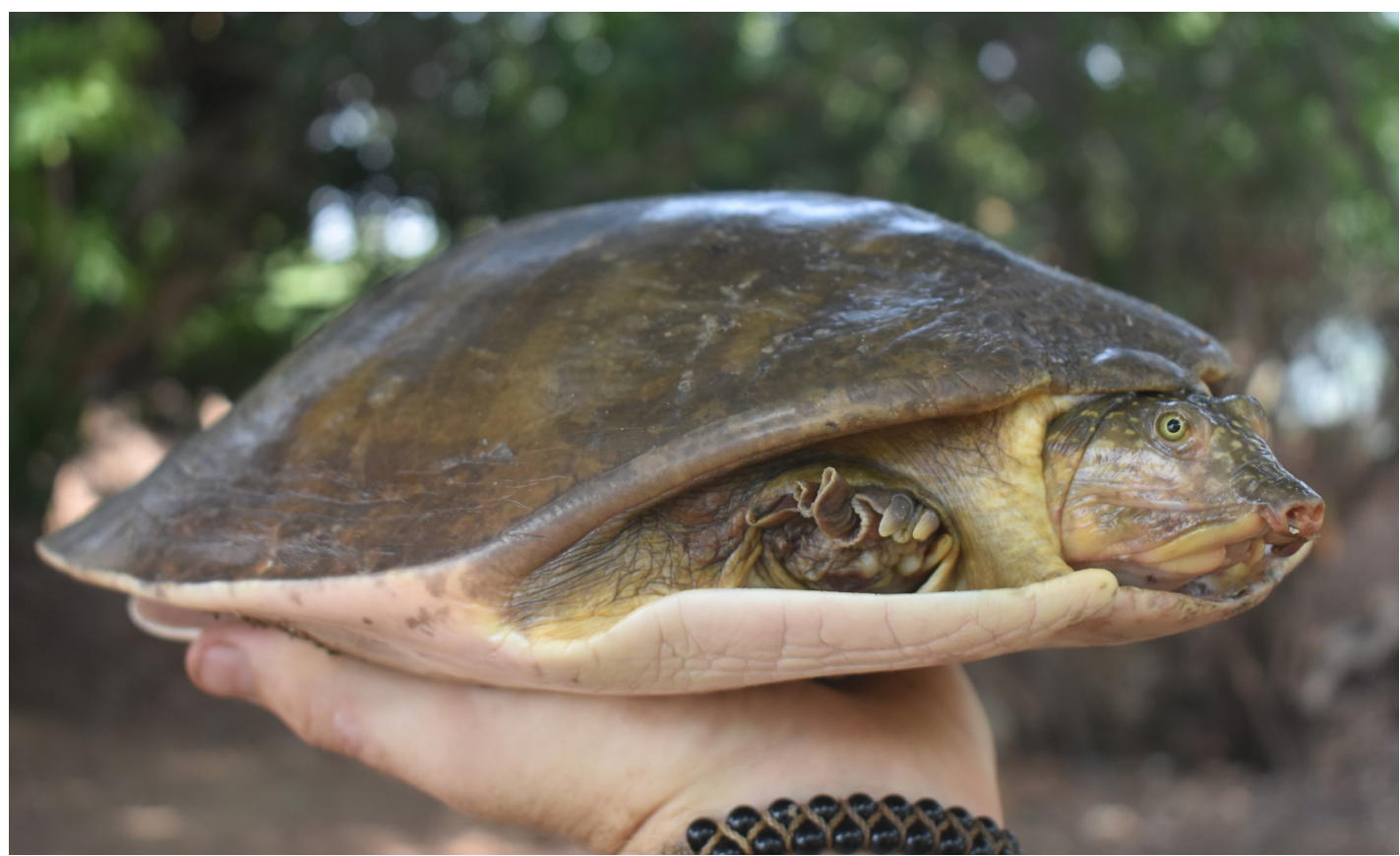

Figure 1. An adult female Cyclanorbis senegalensis caught in the Gambia River near the village of Soucouta, Senegal. The prenuchal in this individual is visible as a small swelling in the carapace just above the eye; $33.8 \mathrm{~cm}$ curved carapace length, $24.0 \mathrm{~cm}$ curved bony carapace length. Photo by Pearson McGovern.

of the currently recognized species was being discussed (Webb 1975).

Based on mitochondrial DNA sequence data, Mazuch et al. (2016) found significant genetic divergence between western (Togo and Benin) and eastern (Ethiopia) populations. They recommended further phylogeographic study, but made no taxonomic recommendations, and no subspecies are currently recognized.

Description. - Cyclanorbis senegalensis is a mediumsized softshelled turtle with distinctive features that are most apparent in the carapace and plastron, including the presence of notably prominent plastral flaps that completely obscure the hind legs and tail. This species, and those in the genus Lissemys, are unique among turtles in having a prenuchal bone (unossified in young individuals) separated

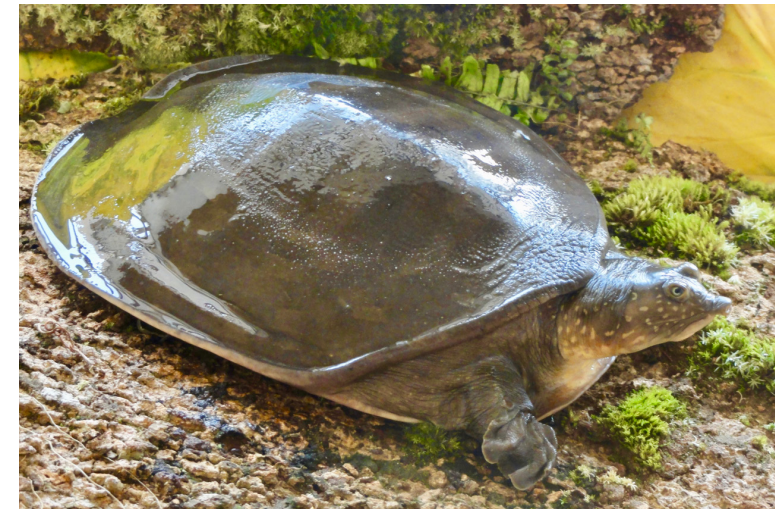

Figure 2. Cyclanorbis senegalensis from Northern Prov., Sierra Leone. Photo by William R. Branch. from the anterior carapacial margin of the nuchal element by a broad, flexible area.

Although there is remarkable variability in the elements that make up the plastron, adult C. senegalensis are typically characterized by the presence of either seven or nine plastral callosities, with a single callosity covering the fused hyo-hypoplastra. More than nine plastral callosities have occasionally been reported (Gramentz 2008). When seven callosities are present, they include a hyo-hypoplastral pair, an epiplastral pair, a gular pair, and a midline ossification over the entoplastron. In most $C$. senegalensis, xiphiplastral callosities are absent. The gular callosities are unique among trionychids and cyclanorbines. These are always present and are located anterior to the epiplastral callosities. During growth, callosities first develop on the hyo-hypoplastra,

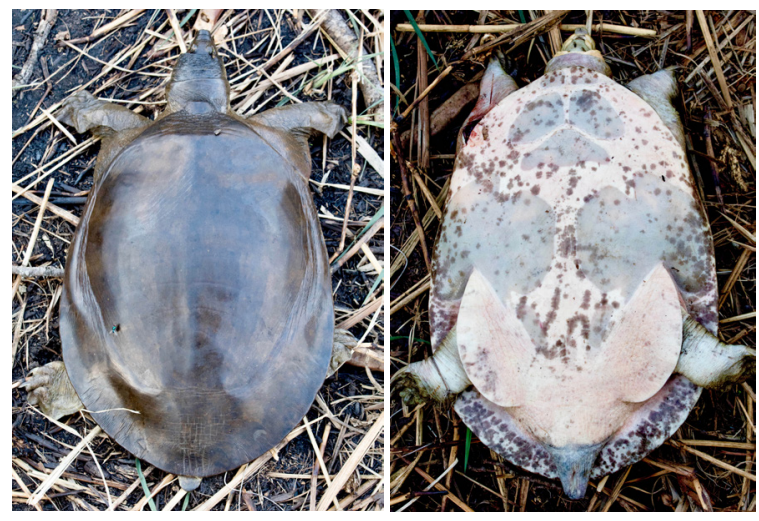

Figure 3. Cyclanorbis senegalensis from western Ethiopia. Photos by Håkan Pohlstrand. 


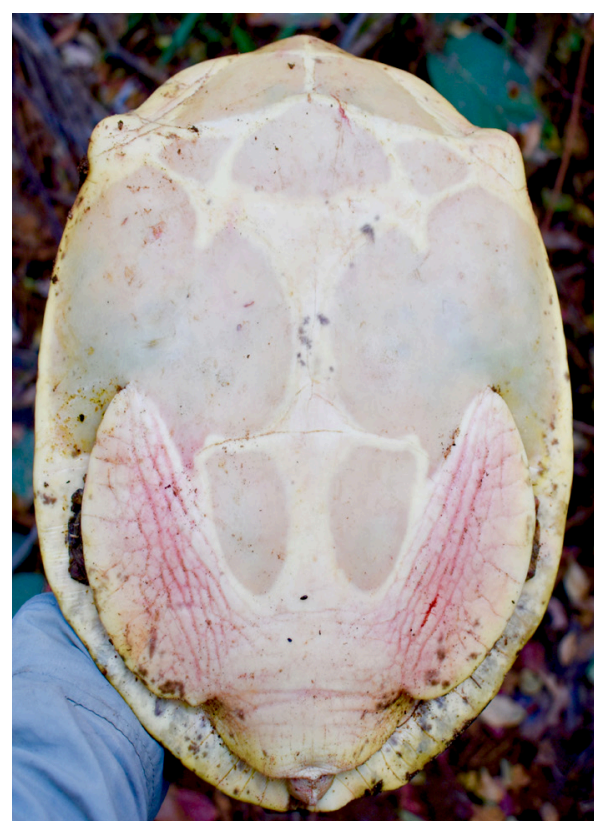

Figure 4. Cyclanorbis senegalensis with 11 plastral callosities found near the village of Sekoto in southeastern Senegal; $23.2 \mathrm{~cm}$ curved bony carapace length, $32.0 \mathrm{~cm}$ curved carapace length. Photo by Pearson McGovern.

followed by the epiplastra, the gular, and lastly the entoplastron (Gramentz 2008). Additional callosities may be present lateral to the epiplastral or entoplastral callosities (e.g., BMNH 65.5.3.75; Gramentz 2008; McGovern, unpubl. data). This large number of plastral callosities is the most reliable character to distinguish this species from young individuals of $C$. elegans ( 2 to 4 callosities), which when fully grown also attain significantly larger sizes than C. senegalensis (Baker et al. 2015). Plastral callosities are textured with fine tubercles arranged in concentric circles.

In mature individuals, the color of the carapace is light brown to blackish olive (see Gray 1860,1870, and Pritchard 1979; gray in preservative). The surface of the carapace is covered with a thick, smooth skin which completely hides the rugosity of underlying bones. The plastron is white,

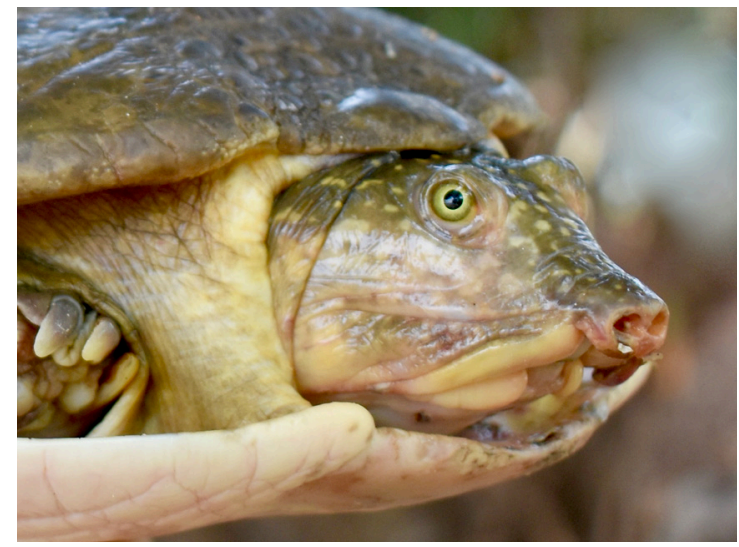

Figure 6. Cyclanorbis senegalensis from Senegal. Photo by Pearson McGovern.

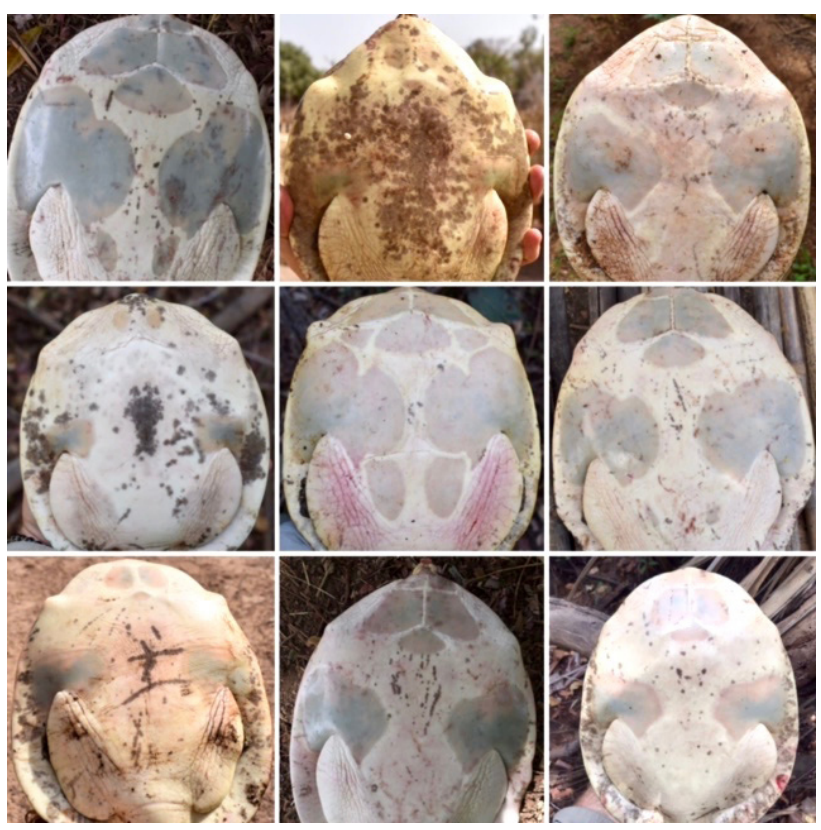

Figure 5. Plastral variation of Cyclanorbis senegalensis captured in southeastern Senegal. Curved bony carapace lengths in $\mathrm{cm}$, left to right by row: Top row: $22.1,15.5,20.6$; middle row: $15.5,23.2$, 27.0; bottom row: 17.5, 24.0, 22.2. Photos by Pearson McGovern.

occasionally clouded with brown or black smudges both centrally and on the femoral flaps that conceal the retracted hind limbs and the caudal flap that conceals the tail, though smudging is often lost with maturity. The head and neck are olive to blackish above, lighter below, often with many symmetrical roundish white-yellow spots and a short white streak in the center of the crown. The upper part of the neck may have symmetrical white marbling.

Skeletal material of this species is most easily identified by an unusual neural series, which, though highly variable, is nearly always divided by pairs of costal bones meeting on the midline (in 19 of 21 specimens examined by Meylan 1987). The work of Hughes (1979) suggested that there is a geographic pattern to the significant variation in the arrangement of the neural bones in this species.

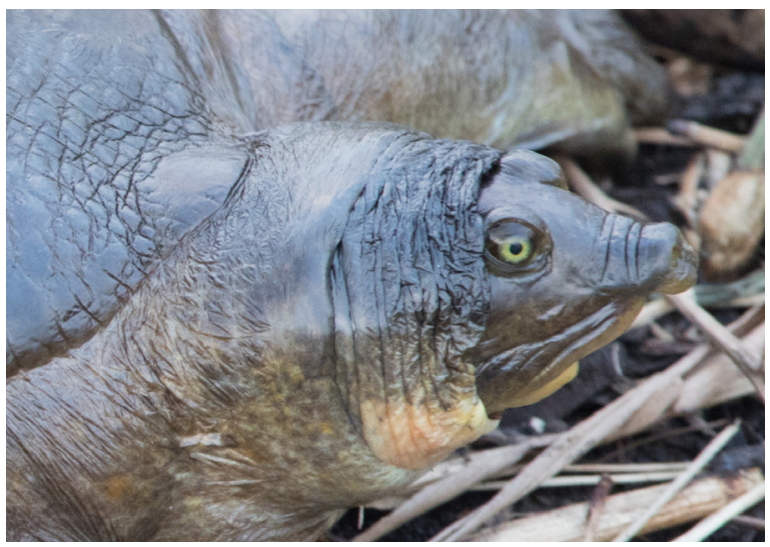

Figure 7. Cyclanorbis senegalensis from Ethiopia. Photo by Håkan Pohlstrand. 

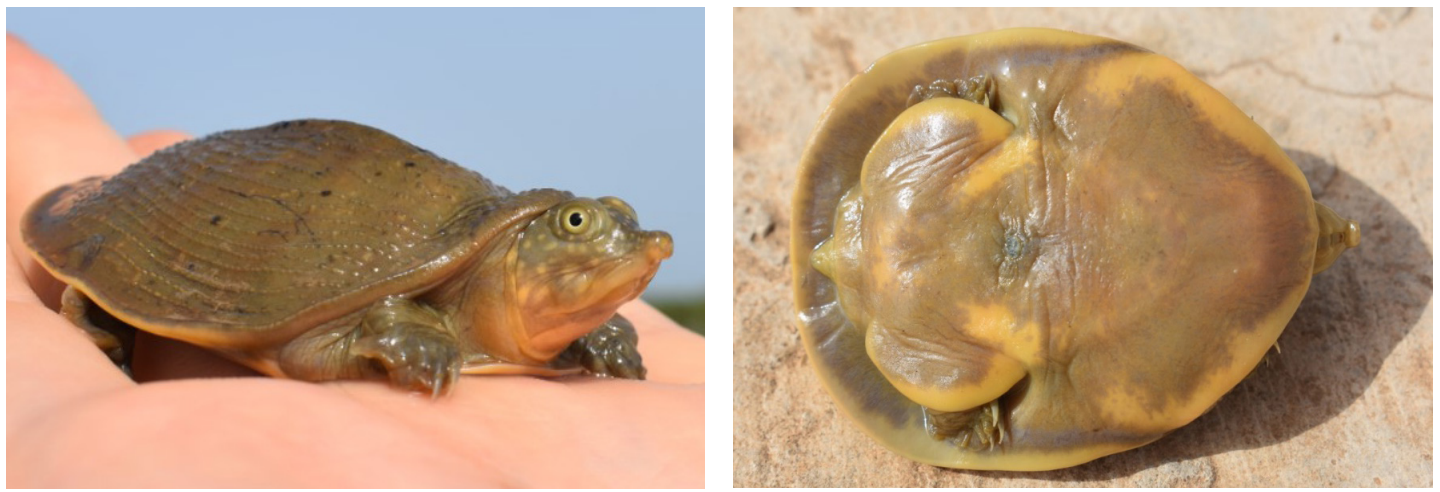

Figure 8. Hatchling Cyclanorbis senegalensis from Niokolo-Koba National Park, Senegal. The unossified prenuchal can be seen as a raised area at the front of the carapace above the eye; $54.1 \mathrm{~mm}$ straight carapace length. Photos by Pearson McGovern.

As the smallest and lightest representative of the African cyclanorbines, C. senegalensis rarely exceeds $35 \mathrm{~cm}$ in curved carapace length (CCL) and $4 \mathrm{~kg}$ in mass (Villiers 1958; Rödel and Grabow 1995; Devaux 1998; Pritchard 2001; Gramentz 2008; Akani et al. 2018). In the most representative published dataset regarding CCL for this species, Akani et al. (2018) measured 63 specimens ( 32 males, 28 females, 3 immature) captured in six countries in the center of the species' range, documenting an average CCL of $23.3 \mathrm{~cm}$ (range, $12.0-34.2 \mathrm{~cm}$ ).

The two largest known specimens were caught in southeastern Senegal and measured 37.0 and $37.9 \mathrm{~cm} \mathrm{CCL}$ (McGovern, unpubl. data). The average for all individuals captured in this area $(n=12)$ was $28.8 \mathrm{~cm}(\mathrm{SD}=5.98$; range, $18.5-37.9 \mathrm{~cm})$. When eight carapaces of individuals consumed by local fishermen were added to the dataset ( $n$ $=20$ ), the average curved carapacial bony disc length was $20.0 \mathrm{~cm}(\mathrm{SD}=3.59$; range, $13.0-27.5 \mathrm{~cm})$. Mean ratios for plastron length (inclusive of the caudal flap) to CCL, curved

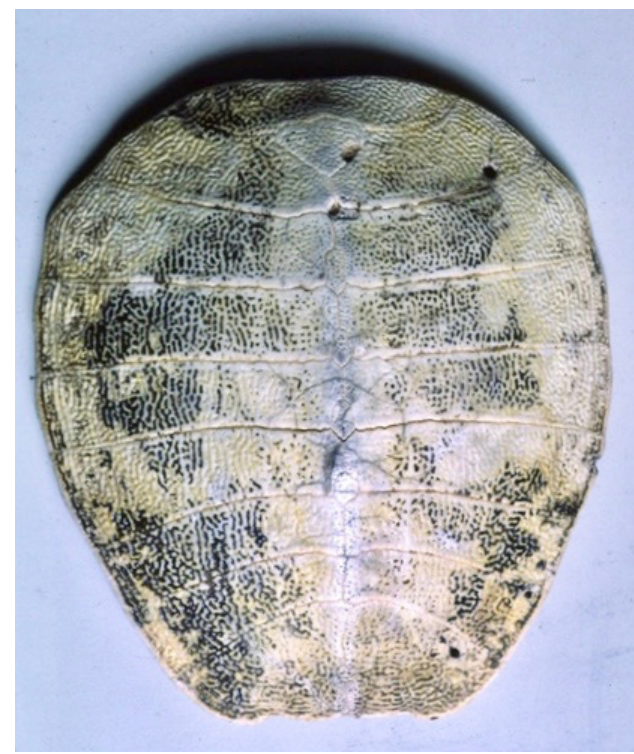

bony disc length to CCL, and plastron length (inclusive of the caudal flap) to curved bony disc length, were $0.908,0.713$, and 1.278 , respectively (McGovern, unpubl.data). The maximum straight carapace length measured for C. sene galensis is 35.5 $\mathrm{cm}$ in a female (Schäfer in Gramentz 2008).

Hatchlings are gray to brown, sparsely spotted with black and with some indistinct lighter mottling, particularly along the ventral margin of the carapace. The plastron may be quite heavily blotched with dark pigment in young individuals (Mazuch et al.2016). The head, neck, and limbs are either gray or brown with fine white spotting. Two wild hatchlings found in the Alwero River of western Ethiopia measured 47.9 and $40.6 \mathrm{~mm}$, respectively (Mazuch et al. 2016). The sole hatchling found during surveys in Senegal measured $54.1 \mathrm{~mm}$ in straight CL, $44.6 \mathrm{~mm}$ in straight carapace width, and had a straight plastron length of 50.1 $\mathrm{mm}$ (McGovern, unpubl. data). Three hatchlings in Kara (Togo) measured 52.8-53.9 $\mathrm{mm}$ straight CL (Luiselli and Segniagbeto, unpubl. data).

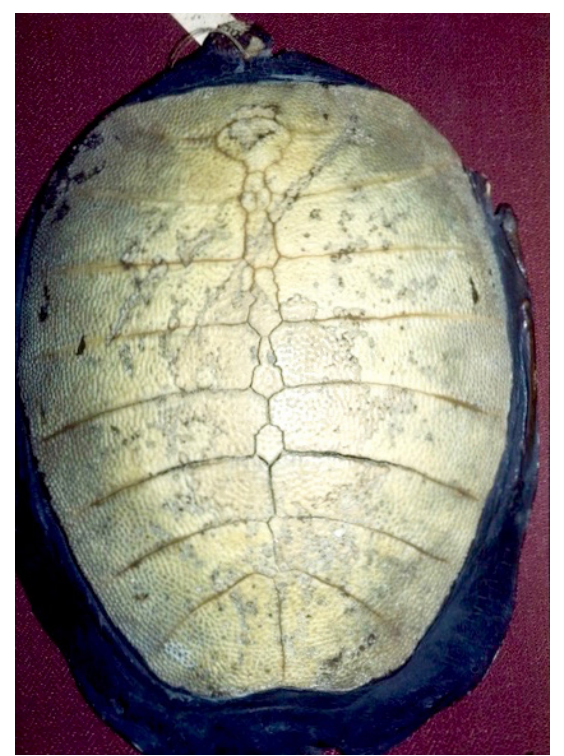

Figure 9. Bony carapaces of Cyclanorbis senegalensis. Left: NMW 125-2 (201 mm), right: BMNH 65.5 .3 .75 (230 mm). Photos by Peter A. Meylan. 


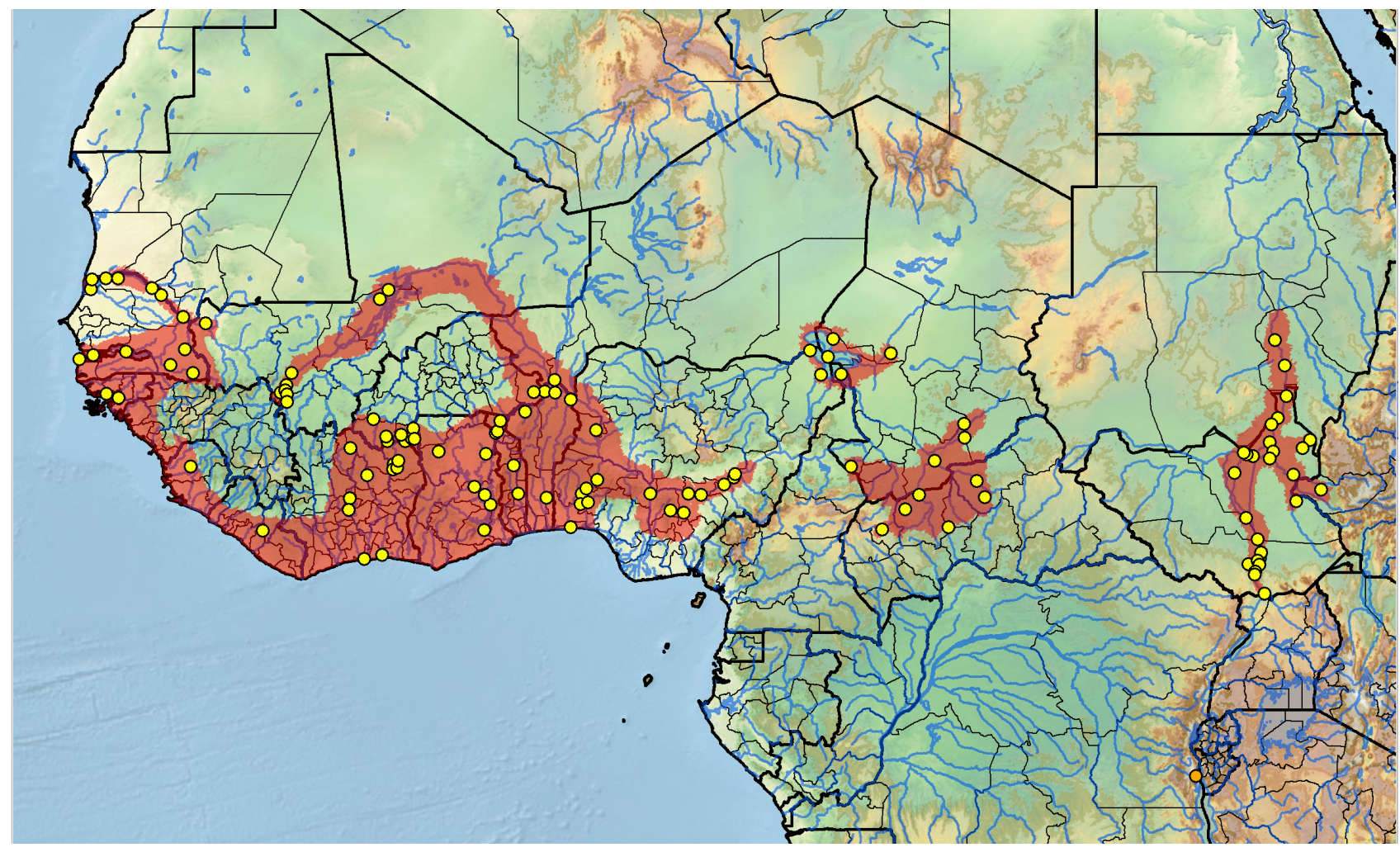

Figure 10. Distribution of Cyclanorbis senegalensis in sub-Saharan Africa. Yellow dots = museum and literature occurrence records of native populations based on Iverson (1992), TTWG $(2017,2021)$, and authors' more recent data; orange dot = probable trade or misidentified specimen; red shading = presumed native historic indigenous range. Distribution based on GIS-defined level 12 HUCs (hydrologic unit compartments) constructed around verified localities and then adding HUCs that connect known point localities in the same watershed or physiographic region, and similar habitats and elevations as verified HUCs (Buhlmann et al. 2009; TTWG $2017,2021)$ and adjusted based on authors' data.

Distribution. - Cyclanorbis senegalensis has an apparently disjunct and fragmented distribution across the sub-Saharan Sahel of Africa from Senegal, Gambia, and Guinea-Bissau in the west, to South Sudan, Sudan, and far western Ethiopia in the east (Iverson, 1992; Mazuch et al. 2016; TTWG 2017,2021). These apparent gaps may be a result of low sampling effort. Broin (1983) reported on the discovery of about a dozen shell fragments of this species from the Holocene at two localities in northern Mali, well north of the current range. Meylan et al. (1990) reported a Pleistocene record from Lake Turkana

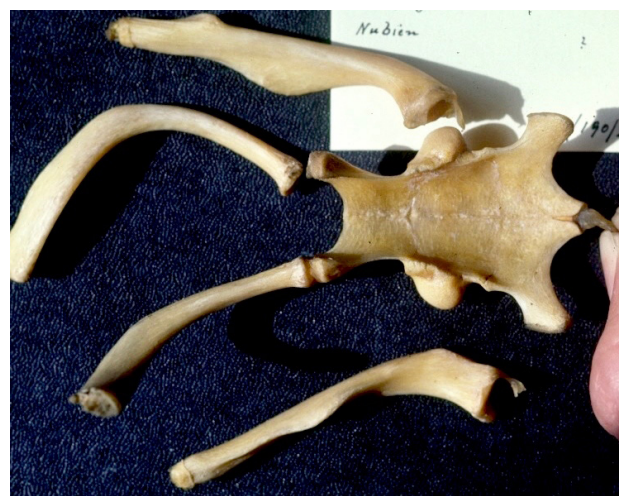

Figure 11. Hyoid apparatus of Cyclanorbis senegalensis (NMW 229). Photo by Peter A. Meylan. in northern Kenya, also well beyond the borders of the confirmed contemporary distribution. Even further south of the current distribution of the species, Karl (2012) examined two presumed $C$. senegalensis fossils from the Plio-Pleistocene of northern Malawi.

Habitat and Ecology. - The few available accounts of the ecology of this species suggest that it is a riverine form and habitat generalist that also occupies seasonal wetlands. Andersson (1937) reported on a collection of four small specimens ( 4.0 to $12.0 \mathrm{~cm} \mathrm{CL}$ ) in river marshes during the rainy season in Gambia, and another large specimen caught on a longline in a river. Hughes (1979) reported at least three specimens taken from the Mole River within Mole National Park, Ghana, and mentioned another from near the Volta River. Based on the capture of 196 C. senegalensis specimens from six range countries, Akani et al. (2018) found that this species prefers medium sized rivers (5-25 m river-bed width) with sparse emergent vegetation, grassy, semi-vegetated banks, and predominantly muddy bottoms. This study compared C. senegalensis to the larger trionychid, Trionyx triunguis, with which it is often sympatric, finding that C. senegalensis is more of a habitat generalist, being found consistently in rivers with varying degrees of both shoreline and emergent vegetation as well as varied 

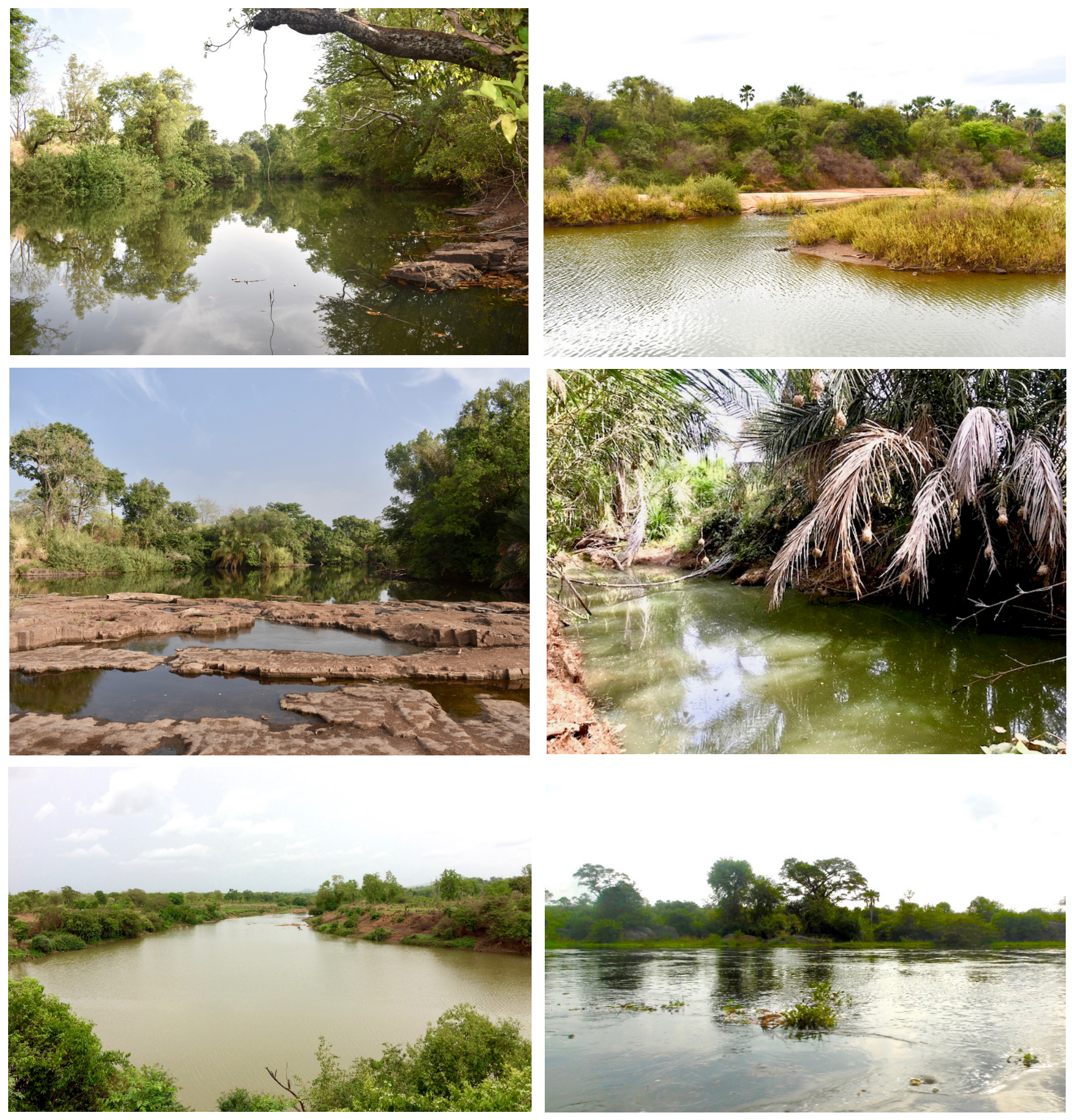

Figure 12. Habitats for Cyclanorbis senegalensis. Top left: Koila Kabe River, southeastern Senegal. Photo by Pearson McGovern. Top right: Gambia River, near Madina in southeastern Senegal. Photo by Pearson McGovern. Middle left: Koila Kabe River, near Khouleya, southeastern Senegal. Photo by Pearson McGovern. Middle right: Kofla, near Sekoto in southeastern Senegal. Photo by Pearson McGovern. Bottom left: Mékrou River, Atakora Dept., northern Benin. Photo by Luca Luiselli. Bottom right: Southern White Nile River, South Sudan. Photo by Luca Luiselli.

substrate bottoms (rocky, sandy, muddy). The greatest partitioning of the available aquatic habitats throughout the overlapping distributions of these species seemed to occur in the largest of rivers ( $>25 \mathrm{~m}$ river-bed width) where $T$. triunguis was the dominant species captured. In Ghana, where it is the most common turtle species in permanent freshwater ecosystems, C. senegalensis is more similar to T. triunguis in its choice of habitat than to sympatric hard-shelled Pelusios species (Pelomedusidae), and its presence was best defined by the density of woody emergent vegetation and inorganic substrates in both benthic and terrestrial zones (Gbewaa et al. 2021). In Benin, the presence of $C$. senegalensis was positively influenced by the presence of high bank vegetation, high aquatic vegetation and low current speed (Luiselli et al. 2020). Though C. senegalensis is captured in rivers 
represented by variable shoreline vegetation, it seems to be most associated with water bodies in Sudanese Savannah and grassland landscapes (Chirio and Ineich 2006; Segniagbeto et al. 2014; though see Segniagbeto et al. 2015 for documentation of this species in gallery forest rivers). Demaya et al. (2019a, 2019b) found $C$. senegalensis primarily in waterbodies off the main river channel (White Nile River) in South Sudan, where the species is sympatric with the larger C.elegans, which is dominant in the main river.

Reproduction. - Siebenrock (1906) described a gravid female $C$. senegalensis with a bony disc length of $22.5 \mathrm{~cm}$ (estimated CCL $=31.6 \mathrm{~cm}$ based on McGovern, unpubl. data) collected in mid-April at Duem (=AdDouiem), Sudan, on the White Nile, that had 6 hard-shelled, almost spherical eggs measuring $36 \mathrm{~mm}$ in diameter. Hatchling emergence likely coincides with the wet season (April-November), suggested by both the discovery of two hatchlings in a riverside temporary pool in Ethiopia in August (Mazuch et al. 2016), one hatchling in a riverside puddle in NiokoloKoba National Park in Senegal in late June (McGovern, unpubl. data), and reports of emerged hatchlings in late May in Guinea-Bissau (Schuhmann, pers. comm. in Gramentz 2008). In Togo, females emerge to nest during the lowest river levels at the end of the dry season (January-February; Maran 2004).

Diet. - The diet of C. senegalensis is largely unknown. In South Sudan, dissection of 12 specimens captured by fishermen revealed the presence of hard-shelled gastropods (in $n=10$ specimens), fish $(n=2)$, arthropods $(n=7)$, and aquatic plants ( $n=4$; Luiselli et al., unpubl. data). Grafe et al. (2004) speculated that years of low frog recruitment in their sampled ephemeral ponds may have been a result of high predatory turtle densities in those years $(C$. senegalensis was the most abundant species in these ponds), though no direct evidence of frog eating was demonstrated. Interestingly, $C$. senegalensis was also presumed by Gray (1864) to feed on hard-shelled gastropods, based on the broadening of the lower jaws, supported by our data from South Sudan (Luiselli et al., unpubl. data). Fishermen in Nigeria, Senegal, South Sudan, and Togo often catch the species on long-lines baited with fish, though many times this is a result of the fleshy carapace or a limb becoming accidentally hooked (McGovern et al., unpubl. data). The presence of a well-developed hyoid apparatus suggests that suck-gape feeding is important in this species as it is in other long-necked softshells (Pritchard 1984).

Parasites and Epibionts. - Cotylaspis [Aspidogaster] lenoiri is a known intestinal endoparasite (Poirier 1886). Terenius et al. (2000) reported on the collection of the tick Amblyomma nuttali from a recently wild-caught $C$. senegalensis held at the Zoological Gardens in Bissau, Guinea-Bissau. The authors acknowledged that this record came from an artificial environment but presumed the tickhost association to be natural.

Population Status. - Few studies have investigated the population status of $C$. senegalensis. In the most comprehensive study to date, consisting of 196 captures from 32 sampling sites in Central African Republic, Nigeria, Ghana, Benin, Togo, and Burkina Faso, Akani et al. (2018) considered individuals to be rare in only one (Ghana) of the 10 documented populations. Further, Gbewaa et al. (2021) considered C. senegalensis as the most common freshwater turtle species in savannah waterbodies in Ghana, and it is very common in Mole National Park, Ghana (Petrozzi and Luiselli, unpubl. data). Luiselli et al. (2020) showed that it is one of the three most common species in Benin. In savannah waterbodies in Nigeria it is also common and widespread (Luiselli, Akani, and Eniang, unpubl. data). Grafe et al. (2004) reported finding $18 \mathrm{C}$. senegalensis in a $60 \mathrm{~m}^{2}$ pond in Comoé National Park, Ivory Coast (Côte d'Ivoire) in 1997. Demaya et al. (2019b) indicated that this species is very common in South Sudan but tended to be less abundant in the southern regions of the country.

Segniagbeto et al. (2014), based on unpublished interviews with local reptile collectors, suggested that the species may be experiencing population declines in Togo. When evaluating the vulnerabilities of the five African trionychid turtles to six threat metrics (extent of distribution, body size, habitat breadth, habits, likeliness of human persecution, and habitat vulnerability), Luiselli (2009) calculated a mean vulnerability score of 2.27 for all five species, with only the two Cyclanorbis scoring above average. Though C.elegans (at 2.83) was considered the only species "seriously exposed to decline," $C$. senegalensis (at 2.33) was the second most vulnerable species in the family and one of four African trionychids whose scores suggested vulnerability to declines (see Table 2 in Luiselli 2009). In a more recent analysis, Luiselli et al. (2021) reported this species to be widespread and locally common in Guinea savannah waterbodies, but clearly declining at altered sites.

Threats to Survival. - Cyclanorbis senegalensis is consumed by humans in both the eastern and western parts of its range. Based on the earlier work of Werner, Loveridge and Williams (1957) reported that "these turtles are hunted by the Bari Tribesmen of the Bahr el Jebel who utilize the carapacial disks as basins, and esteem the fleshy margins for their food value." Flower (1900) reported finding remains (presumably from human consumption) in Renk and Bahr-el-Zeraf, Sudan (now South Sudan). Widespread consumption of this species in South Sudan was also observed by Luiselli et al. in 2017-2021 (unpubl. data), especially by the Bari communities. Hughes (1979) found parts of at least three individuals in a modern midden 


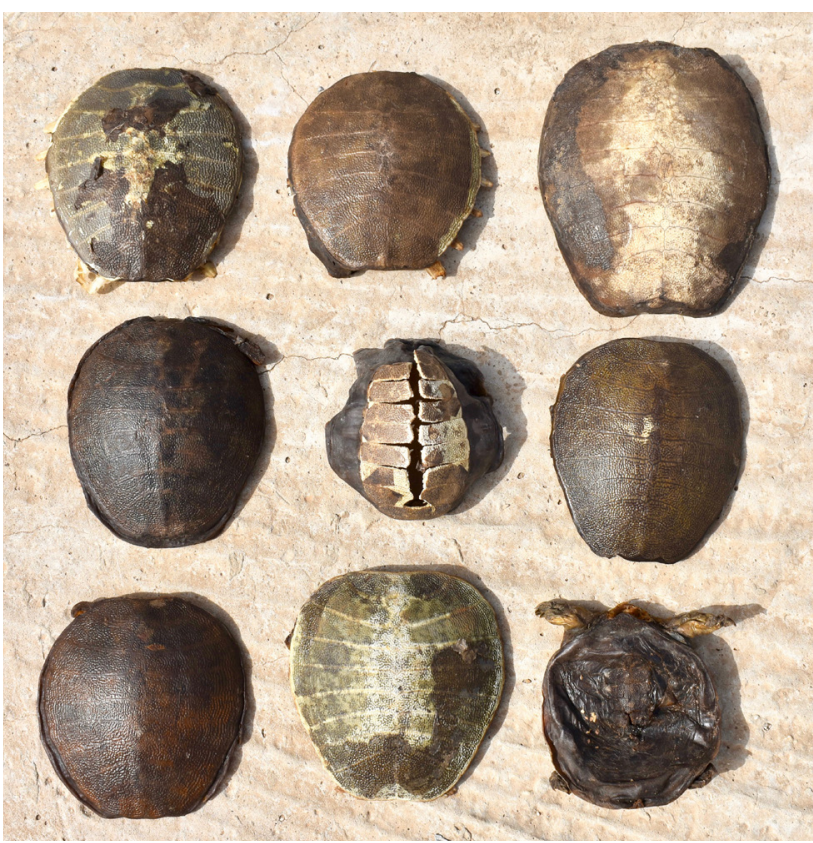

Figure 13. Carapaces of nine Cyclanorbis senegalensis consumed or killed by fishing gear in Senegal. Photo by Pearson McGovern.

in Ghana that also included bones of antelope, crocodile, and python.

Luiselli (2009) considered C. senegalensis as potentially the second most threatened African trionychid based on high habitat vulnerability, high likeliness of either direct or indirect human persecution, and low habitat breadth (though see Rödel and Grabow 1995). In the Kedougou region of southeastern Senegal, this species is most often encountered during the rainy season, at which time it is at risk of being collected for food or of being kept in wells and water basins on people's garden plots as "porters of good luck" (McGovern, unpubl.data).Keeping C.senegalensis in wells was also reported by Andersson (1937) at MacCarthy Island, Gambia, where locals captured turtles while they moved from rivers to marshes in the wet season, to rid their wells of "vermin."

Some live export of this species occurs to supply hobbyists, but details are lacking. The 14 skeletons in the Chelonian Research Institute's Pritchard collection (now at Turtle Conservancy, Ojai, California), all salvaged from pet trade mortalities, were reported to have been exported from Liberia. The species is traded in fetish markets in Togo (Segniagbeto et al.2014), and thus also presumably in other West African countries; five carapaces were documented in April 2021 at the Adjame market in Abidjan, Ivory Coast (Côte d'Ivoire) (McGovern, unpubl. data). Current trade projections approximate 50 live $C$. senegalensis traded per year from Togo, however, this species has also been traded as Trionyx triunguis in the past, making trade estimates difficult (Segniagbeto et al. 2014). D’Cruze et al. (2020) recorded this species on reptile farms in Togo.
The species was formerly found in Lake Guiers, along the northern Senegalese border with Mauritania, until the establishment of the Diama dam in the early 1980s (Ndiaga Boh, pers. comm. to T. Diagne). In general, development and habitat loss and degradation affect local populations of this species but are unlikely to affect the species status more globally.

Conservation Measures Taken. - Cyclanorbis senegalensis has been assessed on the IUCN Red List as Vulnerable (Diagne et al. 2016). It has been included on CITES Appendix II since 2017.

Some populations are protected in National Parks throughout its range, including Aouk and Zakouma National Parks (Chad), Mole National Park (Ghana), Pendjari National Park (Benin), Southern, Bandingilo and Nimule National Parks (South Sudan), Fazao Malfakassa and Togodo National Parks (Togo), Niokolo-Koba National Park (Senegal), Comoé-Leraba National Park (Burkina Faso), and Comoé and Assagny National Parks (Ivory Coast [Côte d'Ivoire]).

Conservation Measures Proposed. - Surveys and abundance studies of this species should be undertaken, both to add biological knowledge and insight and to plan appropriate further conservation steps. An effort should be made to collect genetic material from across the range to allow an examination of the genetic diversity among apparently disjunct populations.

Captive Husbandry. - Successful keepers have reported captive $C$. senegalensis feeding on dead fish, snails, tadpoles, squid, earthworms, mussels, and shrimp (Villiers 1958; Pritchard 1979; Rödel and Grabow 1995; Schäfer in Gramentz 2008). Though likely well below the lifespan of wild individuals, specimens have been reported to survive around 10 years in captivity (Villiers 1958). This species is said to be docile (Pritchard 1979).

Current Research. - This species is currently being studied from the ecological point of view in South Sudan by Luiselli, Gift Simon Demaya, John Sebit Benansio, and Thomas Francis Lado from the University of Juba, in Togo by Luiselli, Gabriel Hoinsoudé Segniagbeto, and Assou Delagnon from the University of Lomé, and in Senegal by McGovern and T. Diagne. Opportunistic surveys have been carried out in Ivory Coast [Côte d'Ivoire] by Luiselli and Sery Gonedele Bi from the University De Boissy, Abidjan, and in Nigeria by Luiselli, Stephanie N. Ajong, Godfrey C. Akani, Nioking Amadi, and Edem A. Eniang from the Lagos State University, Rivers State University of Science and Technology, Port Harcourt, and University of Uyo.

Acknowledgments. - McGovern thanks the Rufford Foundation for funding turtle surveys in Senegal and also Mady Konjira, Sadaba Konjira, and the fishermen around Kedougou, Senegal, especially those from the villages of 
Soucouta, Krenkoko, Sekoto, and Baitilaye for their huge help and collaboration in the field. The authors would like to thank Anders Rhodin and John Iverson for reviewing previous versions of this manuscript and acknowledge Håkan Pohlstrand and William Branch for the use of their photos.

\section{Literature Cited}

Akani, G.C., Eniang, E.A., Amadi, N., Dendi, D., Hema, E.M., Diagne, T., Ségniagbeto, G.H., Di Vittorio, M., GbewaA, S.B., Pauwels, O.S.G., Chirio, L., and Luiselli, L. 2018. Macrohabitat and microhabitat usage by two softshell turtles (Trionyx triunguis and Cyclanorbis senegalensis) in West and Central Africa. Herpetological Conservation and Biology, 13(3):642-651.

Andersson, L.G. 1937. Reptiles and batrachians collected in the Gambia by Gustav Svensson and Birger Rudebeck. Arkiv för Zoologi Stockholm 29(16):1-28.

Baker, P.J., Diagne, T., And Luiselli, L. 2015. Cyclanorbis elegans (Gray 1869) - Nubian Flapshell Turtle. In: Rhodin, A.G.J., Pritchard, P.C.H., van Dijk, P.P., Saumure, R.A., Buhlmann, K.A., Iverson, J.B., and Mittermeier, R.A. (Eds.). Conservation Biology of Freshwater Turtles and Tortoises: A Compilation Project of the IUCN/SSC Tortoise and Freshwater Turtle Specialist Group. Chelonian Research Monographs 5(8):089.1-7.

Bour, R., Dubois, A., And WebB, R.G. 1995. Types of recent trionychid turtles in the Muséum national d'Histoire naturelle, Paris. Dumerilia 2:73-92.

Broln, F. DE. 1983. Cheloniens. In: Petit-Maire, N. and Riser, J. (Eds.). Sahara ou Sahel? Quaternaire Recent du Bassin de Taoudenni (Mali). Marseille, pp. 211-233.

Buhlmann, K.A., Akre, T.S.B., Iverson, J.B., Karapatakis, D., Mittermeier, R.A., Georges, A., Rhodin, A.G.J., van Dijk, P.P., And GibBons, J.W. 2009. A global analysis of tortoise and freshwater turtle distributions with identification of priority conservation areas. Chelonian Conservation and Biology 8(2):116-149.

Chirio, L. And Ineich, I., 2006. Biogeography of the reptiles of the Central African Republic. African Journal of Herpetology 55(1):23-59.

D’Cruze, N.,Harrington,L.A.,Assou, D., Green, J., Macdonald, D.W., Ronfot, D., Segniagbeto, G.H., and Auliya, M. 2020. Betting the farm: A review of Ball Python and other reptile trade from Togo, West Africa. Nature Conservation 40:65-91.

Demaya, G.S., Benansio, J.S., Lado, T.F., Diagne, T., Dendi, D., AND Luiselli, L. 2019a. Rediscovery of the Nubian Flapshell Turtle (Cyclanorbis elegans) in South Sudan. Chelonian Conservation and Biology 18:62-67.

Demaya, G.S., Benansio, J.S., Lado, T.F., Jubarah, S.K., Leju, J., AND LuiselLi, L. 2019b. Local ecological knowledge in South Sudan can help conservation and management of Cyclanorbis elegans. Chelonian Conservation and Biology 18:259-264.

Devaux, B. 1998. Les Tortues du Senegal. La Tortue 44:16-20.

Diagne, T., Luiselli, L., Trape, J.-F., Rödel, M.-O., Baker, P.J., Chirio,L.,Petrozzi, F., And Segniagbeto, G. 2016.Cyclanorbis senegalensis. The IUCN Red List of Threatened Species 2016: e.T6005A96447114.

Duméril, A.H.A. 1861. Reptiles et poissons de l'Afrique occidentale. Étude précédée de considérations générales sur leur distribution géographique.Archives du Muséum d'Histoire Naturelle, Paris 10:138-268.

Duméril, A.M.C. And Bibron, G. 1835. Erpétologie Générale ou Histoire Naturelle des Reptiles. Tome Second. Paris: Roret, $680 \mathrm{pp}$.

FLOWER, S.S. 1900. On some reptiles and batrachians from the White Nile. Proceedings of the Zoological Society of London 1900:967-968

GbewaA, S.B., Oppong, K., Horne, B.D., Tehoda, P., Petrozzi, F., Dendi, D., Akani, G.C., Di Vittorio, M., Ajong, S.N., Pacini, N., FA, J.E., LuiselLi, L. 2021. Community characteristics of sympatric freshwater turtles from savannah waterbodies in Ghana.Wetlands, https://doi.org/10.1007/s13157-021-01459-w.

Grafe, T.U.,Kaminsky,S.K.,BITZ,J.H.,LÜsSOW,H., AND LinsenMaIR, K.E.2004. Demographic dynamics of the afro-tropical pig-nosed frog, Hemisus marmoratus: effects of climate and predation on survival and recruitment. Oecologia 141(1):40-46.

Gramentz, D. 2008. African Flapshell Turtles-The Genera Cyclanorbis and Cycloderma. Frankfurt: Edition Chimaira, $191 \mathrm{pp}$.

Gray, J.E. 1854. Description of a new genus and some new species of tortoises. Proceedings of the Zoological Society of London 1852[1854]:133-135.

Gray, J.E. 1860. On the African Trionices with hidden feet (Emyda). Proceedings of the Zoological Society of London 1860:314-316.

GRAY, J.E. 1864. Revision of the species of Trionychidae found in Asia and Africa, with the descriptions of some new species. Proceedings of the Zoological Society of London 1864:76-98.

GraY,J.E. 1865a. Notice of a new genus and species of the family Trionychidae from Western Africa. Annals and Magazine of Natural History (3)16:204-206.

GraY, J.E. 1865b. On the development of the sternal callosities in Cyclanosteus senegalensis, and on the synonyms of Cyclanosteus and its allied genera. Proceedings of the Zoological Society of London 1865:422-428.

GRAY, J.E. 1869. Notes on the families and genera of tortoises (Testudinata), and on the characters afforded by the study of their skulls. Proceedings of the Zoological Society of London 1869:165-225.

GRAY,J.E. 1870.Notes on a specimen of Cyclanosteus senegalensis living in the Society's gardens. Proceedings of the Zoological Society of London 1870:717-718.

Hughes, B. 1979. Occurrence of the freshwater trionychid turtles Cyclanorbis elegans and C. senegalensis in Ghana. Bulletin de l'Institut Fondamental d'Afrique Noire 41A:193-205.

Iverson, J.B. 1992. A Revised Checklist with Distribution Maps of the Turtles of the World. Richmond, IN: Privately printed, 363 pp.

KARL, H.-V. 2012. Human consumption of turtles of the Homo rudolfensis site Uraha (Malawi, East Africa). Archaeofauna 21(1):267-279.

Loveridge, A. AND Williams, E.E. 1957. Revision of the African tortoises and turtles of the suborder Cryptodira. Bulletin of the Museum of Comparative Zoology 115:163-557.

LuiselLi, L. 2009. A model assessing the conservation threats to freshwater turtles of Sub-Saharan Africa predicts urgent need for continental conservation planning. Biodiversity and Conservation 18(5):1349-1360.

Luiselli, L., Akani, G. C., Ajong, S. N., George, A., Di Vittorio, M., Eniang, E. A., Dendi, D., Hema, E.M., Petrozzi, F., and FA, J. E. 2020. Predicting the structure of turtle assemblages along a megatransect in West Africa. Biological Journal of the 
Linnean Society 130:296-309.

Luiselli, L. Diagne, T. and McGovern, P. 2021. Prioritizing the next decade of freshwater turtle and tortoise conservation in West Africa. Journal for Nature Conservation 60:125977.

Maran, J. 2004. Le trionyx á clapets du Sénégal. La Tortue 67:46-51.

Mazuch, T., Trailin, V., Fritz, U., and Vamberger, M. 2016. Senegal Flapshell Turtle (Cyclanorbis senegalensis) in Ethiopia (Testudines: Trionychidae). Amphibian and Reptile Conservation 10(2):1-5.

MeYLan,P.A. 1987.The phylogenetic relationships of soft-shelled turtles (family Trionychidae). Bulletin of the American Museum of Natural History 186:1-101.

Meylan, P.A., Weig, B.S., and Wood, R.C. 1990. Fossil softshelled turtles (family Trionychidae) of the Lake Turkana Basin, Africa. Copeia 1990:508-528.

PoIrIER, J. 1886. Trématodes nouveaux ou peu connus. Bulletin de la Société Philomathique de Paris series 7, 10:20-40.

PritchaRd, P.C.H. 1979. Encyclopedia of Turtles. Neptune, NJ: TFH Publications, $895 \mathrm{pp}$.

PritchaRd, P.C.H. 1984. Piscivory in turtles, and evolution of the long-necked Chelidae. In: Ferguson, M.W.J. (Ed.). The Structure, Development and Evolution of Reptiles. Symposia of the Zoological Society of London 52:87-110.

PRITCHARD, P.C.H.2001. Observations on body size, sympatry, and niche divergence in softshell turtles (Trionychidae). Chelonian Conservation and Biology 4(1):5-27.

Rochebrune, A.T. 1884. Faune de la Sénégambie.Reptiles. Paris: O. Dom, $221 \mathrm{pp}$.

Rödel, M.O. and Grabow, K. 1995. Die Schildkröten und Krokodile des Comoé-Nationalparks, Elfenbeinküste (Reptilia: Testudines et Crocodylia). Faunistische Abhandlungen, Staatliches Museum für Tierkunde Dresden 20:133-144.

Segniagbeto, G.H., Bour, R., Ohler, A., Dubois, A., Rödel, M.O., Trape, J.F., Fretey, J., Petrozzi, F., and Luiselli, L. 2014. Turtles and tortoises of Togo: historical data, distribution, ecology, and conservation. Chelonian Conservation and Biology 13(2):152-165.

Segniagbeto, G.H., Afiademagno, K., Akani, G.C., Petrozzi, F., AND Luiselli, L. 2015. Sex ratio, size structure and morphometrics of turtle populations from Togo, West Africa.
Herpetozoa 28(1-2):29-38.

SIEBENROCK,F. 1906.Ergebnisse einerzoologischen Forschungsreise von Dr.Franz Werner nach Ägyptenund imägyptischen Sudan.IV. Krokodile und Schildkröten. Sitzungsberichte der Kaiserlichen Akademie der Wissenschaften in Wien (MathemathischNaturwissenschaftliche Klasse) 115(1):817-839.

Terenius, O., Mejlon, H.A., and Jaenson, T.G.T. 2000. New and earlier records of ticks (Acari: Ixodidae, Argasidae) from Guinea-Bissau. Journal of Medical Entomology 37(6):973-976.

TTWG [Turtle Taxonomy Working Group: Rhodin, A.G.J., Iverson, J.B., Bour, R., Fritz, U., Georges, A., Shaffer, H.B., AND van DiJK, P.P.]. 2017. Turtles of the World: Annotated Checklist and Atlas of Taxonomy, Synonymy, Distribution, and Conservation Status (8th Ed.). Chelonian Research Monographs 7:1-292.

TTWG [Turtle TAXonomy Working Group: Rhodin, A.G.J., Iverson, J.B., Bour, R., Fritz, U., Georges, A., Shaffer, H.B., AND van DiJK, P.P.]. 2021. Turtles of the World: Annotated Checklist and Atlas of Taxonomy, Synonymy, Distribution, and Conservation Status (9th Ed.). Chelonian Research Monographs 8:1-472.

Villiers, A. 1958. Tortues et crocodiles de l'Afrique noire Française. Institut Francais d'Afrique Noire, Initiations Africaines 15:1-354.

Webi, R.G. 1975. Types of two names of African softshell turtles of the genus Cyclanorbis (Testudines: Trionychidae). Herpetologica 31(3):348-350.

\section{Citation Format for this Account:}

McGovern, P., Diagne, T., Diagne, L., Luiselli, L., and Meylan, P.A. 2021. Cyclanorbis senegalensis (Duméril and Bibron 1835) - Sahelian Flapshell Turtle, Senegal Flapshell Turtle. In: Rhodin, A.G.J., Iverson, J.B., van Dijk, P.P., Stanford, C.B., Goode, E.V., Buhlmann, K.A., and Mittermeier, R.A. (Eds.). Conservation Biology of Freshwater Turtles and Tortoises: A Compilation Project of the IUCN/SSC Tortoise and Freshwater Turtle Specialist Group. Chelonian Research Monographs 5(15):114.1-10. doi: 10.3854/crm.5.114.senegalensis.v1.2021; www.iucn-tftsg.org/cbftt/. 